\title{
The effect of rumen degradable protein level and source on the duodenal essential amino acid profile of sheep
}

\author{
J. vanE. Nolte ${ }^{\#}$ and A.V. Ferreira* \\ Department of Animal Sciences, University of Stellenbosch, Private Bag X1, Matieland 7602, South Africa
}

\begin{abstract}
Two trials were conducted to determine the effects of rumen degradable protein (RDP) level and source on the duodenal essential amino acid (AA) composition of Dohne Merino wethers. The animals had ad libitum access to wheat straw (32 g crude protein (CP)/kg DM; $742 \mathrm{~g}$ neutral detergent fibre (NDF) $/ \mathrm{kg}$ $\mathrm{DM}$ ) and water. In the first experimental treatments casein provided 0, 40, 80, 120 and $160 \mathrm{~g}$ supplemental $\mathrm{RDP} / \mathrm{d}$. In experiment two, urea-nitrogen replaced 0, 25, 50, 75 and $100 \%$ of the true protein in the isonitrogenous treatments. Expressing essential AA concentration as a percentage of duodenal protein indicated that increasing RDP levels tended to decrease arginine, but significantly increased tryptophan concentrations. Histidine, isoleucine, leucine, lysine, methionine, phenylalanine, threonine, valine and total essential AA concentrations were not affected by dietary RDP level. Increasing the urea-N content of RDP supplements significantly decreased isoleucine, leucine, lysine, phenylalanine, tryptophan, valine and total essential amino acid (TEAA) concentrations. Histidine and threonine proportions also tended to decrease with higher non-protein $\mathrm{N}$ levels. When the essential AA profile is expressed in relation to lysine, the concentrations of histidine, leucine, phenylalanine and threonine decreased significantly. Arginine and valine showed a decreasing trend and tryptophan increased significantly as RDP levels were raised. The largest differences appeared between 0 and $40 \mathrm{~g}$ RDP supplementation, while the AA patterns for the rest of the treatments remained relatively constant. Substituting urea for true RDP induced a variable response in arginine and isoleucine, but did not affect any of the other AA's. Increasing RDP intakes significantly increased the duodenal flow of every essential AA, except arginine, and showed a strong tendency to increase TEAA flow as well. Replacing true RDP with urea significantly reduced the flow of methionine and tryptophan and also tended to decrease lysine availability in the duodenum. Individual AA and TEAA flow to the duodenum were also numerically decreased by a minimum of $34 \%$ as urea-N was increased. It appears that the qualitative duodenal essential AA profile in sheep fed low quality forages is relatively insensitive to RDP level or source. The daily essential AA flow to the duodenum seems to be compromised by urea substitution for true RDP.
\end{abstract}

Keywords: Amino acid, microbial protein, rumen degradable protein, urea, casein

${ }^{\#}$ Corresponding author. E-mail: Joubert.Nolte@meadowfeeds.co.za

* Present address: P.O. Box 3123, Matieland 7602, South Africa

\section{Introduction}

Sheep often subsist on low quality roughages, such as crop residues and dry forages, for considerable parts of the year. Nitrogen $(\mathrm{N})$ is generally considered to be the first limiting nutrient for ruminants grazing low quality forages (Kempton \& Leng, 1979; Freeman et al., 1992; Mawuenyegah et al., 1997). When N requirements are met, microbial growth will be enhanced, as well as rumen fermentation. This implies that the structural carbohydrates (cellulose and hemicellulose) will be more extensively fermented. The fermentation of carbohydrates provides most of the energy supply to rumen microbes and is the main driving force behind a productive rumen microbial population (Balch, 1967; Henning et al., 1993). The growth rate of rumen microbes is also greatly affected by the availability of ammonia, peptides and amino acids (AA's) (Kang-Meznarich \& Broderick, 1981; Argyle \& Baldwin, 1989), but the effects of protein source on rumen microbial growth rate are limited when energy deficient diets are fed (Balch, 1967). When carbohydrate availability allows growth, $66 \%$ of the non-structural carbohydrate microbial protein originates from peptides and 34\% from ammonia. When carbohydrates are lacking all peptide $\mathrm{N}$ is converted to ammonia (Russell et al., 1992). Sugar and starch degrading bacteria require ammonia and AA's or peptides for growth, while cellulolytic bacteria utilise ammonia as the chief N source (Russell et al., 1992). Bryant \& Robinson (1962) 
indicated that $82 \%$ of rumen bacteria can grow with ammonia as the only $\mathrm{N}$ source, $25 \%$ would not grow unless ammonia was present and 56\% could utilise either ammonia or AA's. In contrast, Carro \& Miller (1999) reported that both structural and non-structural carbohydrate fermenting bacteria could utilise ammonia as well as pre-formed AA's as a $\mathrm{N}$ source. It seems that ammonia is acknowledged as the primary $\mathrm{N}$ source for the growth of rumen microbes (Nolan, 1975; Aharoni et al., 1991), but that AA's and peptides also play an important role in the $\mathrm{N}$ supply to rumen microorganisms. Stimulating rumen microbial growth via urea supplementation holds considerable financial benefits in terms of the cost of the protein supplement, but may be inferior to natural protein in terms of animal performance (Helmer \& Bartley, 1971).

Intestinal protein primarily consists of undegraded dietary protein, microbial protein (40-80\%; Owens \& Bergen, 1983; Sniffen \& Robinson, 1987) and endogenous protein (9-12\% of non-ammonia-N; NRC, 2001). Therefore, the efficiency of microbial growth and the AA composition of rumen microbes are decisive to the quantitative and qualitative AA supply in the intestines and subsequent animal performance. Firkins et al. (1986) reported on the ability of the microbial population to increase the ratio of essential AA's to non-essential AA's, and thus improve the protein quality entering the duodenum. The objective of this study was to determine: (a) whether the duodenal essential AA profiles, pre-dominantly derived from microbial protein of sheep fed a low-protein, roughage diet supplemented with casein, are affected by rumen degradable protein (RDP) concentration (Experiment 1), and (b) the effect of substituting urea for true protein (casein) on the essential AA profile in the duodenum (Experiment 2).

\section{Material and Methods}

Five Dohne Merino wethers fitted with rumen and duodenum cannulae, the latter located proximally to the entrance of common bile duct, were used in a $5 \times 5$ Latin square experimental design to evaluate the effects of increasing RDP levels on the essential AA profile in the duodenum. The animals with a mean live weight of $60.0 \pm 2.87 \mathrm{~kg}$ were individually housed in metabolism cages and had ad libitum access to wheat straw (Table 1) and water. The wheat straw was chopped into $50 \mathrm{~mm}$ pieces with a hammer mill and offered at $140 \%$ of the average intake of the previous five days for each individual animal. Experimental treatments provided supplemental RDP at 0, 40, 80, 120 and $160 \mathrm{~g}$ RDP/d, respectively. The RDP in the form of calcium caseinate (900 g crude protein/kg; 100\% rumen degradable) was dissolved in $1.2 \mathrm{~L}$ water, divided into two equal portions and administered intraruminally at 07:00 and 19:00 just before offering the forage. To prevent possible trace and macro mineral deficiencies, a mineral premix (260 g NaCl/kg, $160 \mathrm{~g} \mathrm{Ca} / \mathrm{kg}, 80$ g P/kg, $120 \mathrm{~g} \mathrm{~S} / \mathrm{kg}, 0.04 \mathrm{mg} \mathrm{I} / \mathrm{kg}, 0.01 \mathrm{mg} \mathrm{Co} / \mathrm{kg}, 2.5 \mathrm{mg} \mathrm{Mn} / \mathrm{kg}$ and $2.2 \mathrm{mg} \mathrm{Zn/kg)} \mathrm{was} \mathrm{formulated}$ according to the NRC (1985) and the mineral content of wheat straw. This supplement was infused intraruminally with the morning supplements at $19.05 \mathrm{~g} /$ wether/d. The N:S ratio was manipulated to be below $10: 1$ and peaked at $0.35 \%$ of DM intake. That is below the maximum tolerable level of $0.4 \%$ for dietary sulphur from sodium sulphate (NRC, 1985).

Table 1 Chemical composition of wheat straw and calcium caseinate on a dry matter (DM) basis

\begin{tabular}{lcccc}
\hline \multirow{2}{*}{ Nutrient } & Wheat straw & Casein & Urea & Maize starch \\
\cline { 2 - 5 } & & & $\mathrm{g} / \mathrm{kg} \mathrm{DM}$ & 903 \\
Dry matter & 935 & 891 & 993 & 0 \\
Ash & 43 & 29 & 0 & 11 \\
Crude protein & 32 & 900 & 290 & 1 \\
Neutral detergent fibre & 742 & 0 & 0 & 0 \\
Acid detergent fibre & 536 & 0 & 0 & 5 \\
Fat & 9 & 2 & 7 & \\
\hline
\end{tabular}

Animals were allowed to adapt to the diet and their specific supplements for the first 14 days of each period. From days 15 to 18 samples of the wheat straw were taken at each feeding time to form one representative sample for each period. Duodenal samples $( \pm 50 \mathrm{~mL})$ were taken at 6 -h intervals via the Ttype duodenal cannula during days 16 to 18, and frozen immediately. Sampling time was advanced two hours each day to obtain samples on every even hour of a 24-h period. At 06:00 and 15:00 on day 19 the 
rumens of the sheep were completely emptied via their rumen cannulae, the content weighed and immediately returned. Rumen volume was used to calculate daily duodenal flow. According to Owens \& Goetsch (1986) passage rate can be taken as $50 \%$ of the average fluid dilution rate over all five treatments to calculate duodenal flow. Fluid dilution rate was measured by infusing $15 \mathrm{~mL}$ Cr-EDTA (360 mg Cr/15 mL; Uden et al., 1980) into various ruminal sites at 06:00 on day 20. Twenty $\mathrm{mL}$ samples of ruminal fluid were extracted at $0,3,6,9,12$, and $24 \mathrm{~h}$ for analysis of $\mathrm{Cr}$ concentration, and frozen immediately.

Ruminal fluid was extracted by a specially developed device, which consisted of the casing of a $5 \mathrm{~mL}$ syringe, inserted into an in situ degradation bag with $50 \mu$ diameter pores. The syringe had 25 pores with diameters of $3 \mathrm{~mm}$ each and the open end was blocked with a rubber stopper. A $200 \mathrm{~mm}$ long rubber tube was connected to the nozzle of the syringe and passed through the cork of the rumen fistula. The tube was connected externally to a small tap that could be attached to a $60 \mathrm{~mL}$ syringe to extract ruminal fluid. Merits for using this apparatus are that the tap is only opened during extraction and thus conditions in the rumen are kept anaerobic and constant. In addition, ruminal fluid obtained in this manner is clean and free of large feed particles.

The five dietary samples were ground with a Scientec Hammer Mill (Peter Rassloff, Instruments \& Services (PTY) Ltd.) to pass a $1 \mathrm{~mm}$ screen and combined into one composite sample. Dry matter (DM) content of the feed was determined by drying the samples for 24 hours in a convection oven at $100{ }^{\circ} \mathrm{C}$, whereafter the samples were ashed at $500{ }^{\circ} \mathrm{C}$ for $5 \mathrm{~h}$ to determine organic matter (OM) content (AOAC, 1995). The feed samples were also analysed for acid detergent fibre (ADF; AOAC, 1995) and neutral detergent fibre (NDF; Van Soest \& Wine, 1967). The duodenal samples were lyophilised, equivalent quantities from every sample pooled for each wether within each period and finely ground with a Scientific Apparatus sample mill (Arthur H. Thomas Co., Philadelphia, PA). Duodenal and dietary samples were analysed for N content using a Leco Auto Analyser (Model FP 428) and after 22 h of acid hydrolysis (6 N $\mathrm{HCl}$ ) at $110{ }^{\circ} \mathrm{C}$ the AA composition was determined with a Beckman System 7300 high performance analyser (AOAC, 1995). Chromium concentration was measured with a radial emission, inductively coupled plasma spectrometer (Liberty Series II) after ruminal fluid samples were diluted (1:2 dilution). Fluid dilution rate was determined by regressing the natural logarithm of Cr concentration on sampling time (Warner \& Stacy, 1968).

Streptomyces griseus protease incubation was used to determine the protein degradability of wheat straw and casein at $48 \mathrm{~h}$ (Krishnamoorthy et al., 1983; Broderick, 1994). Passage rate used in the calculations was taken as $50 \%$ of the average fluid dilution rate (Owens \& Goetsch, 1986) over all five treatments.

After the data were analysed for differences using ANOVA, multiple comparisons of means, using the t-test, were performed (SAS, 1994). For the second trial, 25 Dohne Merino wethers were used in a randomised block design. Isonitrogenous treatments provided $3.3 \mathrm{~g} \mathrm{RDP} / \mathrm{kg} \mathrm{BW}^{0.75}$ for optimal feed intake and digestion (Nolte et al., 2003), but respectively contained 0, 25, 50, 75 and 100\% urea-N. Further experimental and sampling procedures, chemical and statistical analyses were similar to experiment one.

\section{Results and Discussion}

The protein degradability of wheat straw after an incubation of 48 hours in the rumen was $66 \%$. Due to the slow rumen turnover of fibrous diets (Del Curto et al., 1990; Hannah et al., 1991) and the quick fermentation of casein and urea, the protein degradability of the RDP supplements was estimated to be almost complete. Therefore, it was assumed that the essential AA composition of the duodenal digesta in these experiments derived essentially from microbial protein.

Tryptophan concentration increased $(P<0.0001)$ and arginine tended to decrease $(P=0.06)$ with increasing levels of RDP supplements (Table 2), suggesting that the AA composition of rumen bacteria might be altered slightly by nutritional factors. Supporting data by Clark et al. (1992) and Rulquin et al. (1998) indicated differences in bacterial AA composition due to species, separation and analysis methodology or nutritional factors such as roughage to concentrate ratios or feed intake. Supplementing true RDP to sheep consuming N deficient diets increased feed intake (Del Curto et al., 1990; Matejovsky \& Sanson, 1995), as well as digestible organic matter intake, microbial efficiency and daily microbial $\mathrm{N}$ flow to the duodenum (Nolte et al., 2003). This may lead to changes in the physiological state of bacterial cells, altering their cell wall to protoplasm ratio and, thus, the AA proportions (Rodriguez et al., 2000). An 
increased feed intake is usually also associated with higher rumen outflow rates and since protein increases somewhat slower than bacterial cell mass, an improved bacterial growth rate implies a moderate decrease in the protein content of bacteria (Rodriguez et al., 2000). However, a reduced protein content in rumen bacteria does not necessarily imply a decreased supply of microbial protein to the duodenum, since the effect of an increased feed intake, as observed by Nolte (2000) and Nolte et al. (2003) on daily microbial N flow to the duodenum, may override the lower microbial protein concentration.

However, increasing supplemental RDP levels did not affect histidine, isoleucine, leucine, lysine, methionine, phenylalanine, threonine, valine or total essential amino acid (TEAA) concentrations in the duodenums of sheep fed a basal diet of wheat straw $(P \geq 0.29)$. The reduced protein content of bacteria caused by increased microbial growth rates (Rodriguez et al., 2000), therefore appears to be more associated with the nonessential AA concentrations. Since eight of the 10 essential AA's, as well as the TEAA concentration were not affected by supplemental RDP levels, the qualitative duodenal essential AA profile appeared to be relatively constant. Leibholz (1972), Storm \& Ørskov (1983) and Cecava \& Parker (1993) also reported constant AA patterns for microbial protein. Despite conflicting reports in the literature the results from the present study suggest a reasonably constant essential AA pattern for microbial protein, irrespective of dietary RDP level.

Table 2 The effect of increasing rumen degradable protein (RDP) levels and different RDP:non-protein nitrogen (NPN) ratios on the essential amino acid composition in the duodenal digesta of sheep fed low quality forage

\begin{tabular}{|c|c|c|c|c|c|c|c|}
\hline \multirow{3}{*}{ Amino acid } & \multicolumn{5}{|c|}{ Supplemental RDP (g/d) } & \multirow{3}{*}{$\mathrm{SEM}^{1}$} & \multirow{3}{*}{$\mathrm{P}$} \\
\hline & 0 & 40 & 80 & 120 & 160 & & \\
\hline & \multicolumn{5}{|c|}{ Essential $\mathrm{AA}^{2}$ (g/100 g crude protein) } & & \\
\hline Arginine & 8.02 & 10.70 & 5.52 & 5.90 & 3.92 & 0.81 & 0.06 \\
\hline Histidine & 1.20 & 1.16 & 1.14 & 1.15 & 1.10 & 0.02 & 0.75 \\
\hline Isoleucine & 3.73 & 3.76 & 3.69 & 3.65 & 3.57 & 0.06 & 0.88 \\
\hline Leucine & 5.72 & 5.61 & 5.50 & 5.40 & 5.30 & 0.09 & 0.67 \\
\hline Lysine & 5.91 & 6.05 & 5.93 & 5.83 & 5.68 & 0.11 & 0.89 \\
\hline Methionine & 0.70 & 0.72 & 0.73 & 0.64 & 0.70 & 0.01 & 0.29 \\
\hline Phenylalanine & 3.46 & 3.36 & 3.32 & 3.24 & 3.18 & 0.05 & 0.53 \\
\hline Threonine & 3.70 & 3.76 & 3.62 & 3.51 & 3.42 & 0.07 & 0.51 \\
\hline Tryptophan & 1.46 & 1.71 & 1.96 & 1.96 & 2.08 & 0.06 & $<0.01$ \\
\hline Valine & 4.69 & 4.62 & 4.50 & 4.45 & 4.36 & 0.07 & 0.64 \\
\hline \multirow[t]{4}{*}{ TEAA $^{3}$} & 38.59 & 41.45 & 35.92 & 35.73 & 33.30 & 1.06 & 0.13 \\
\hline & \multicolumn{5}{|c|}{ Supplemental N from urea (\%) } & & \\
\hline & 0 & 25 & 50 & 75 & 100 & & \\
\hline & \multicolumn{5}{|c|}{ 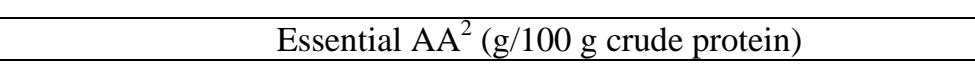 } & & \\
\hline Arginine & 5.54 & 5.71 & 3.79 & 4.63 & 8.57 & 0.63 & 0.11 \\
\hline Histidine & 1.29 & 1.62 & 1.14 & 1.04 & 0.93 & 0.08 & 0.11 \\
\hline Isoleucine & 4.02 & 3.54 & 3.64 & 3.33 & 2.97 & 0.12 & 0.03 \\
\hline Leucine & 5.85 & 5.44 & 5.43 & 4.98 & 4.44 & 0.17 & 0.05 \\
\hline Lysine & 6.69 & 6.94 & 6.12 & 5.51 & 4.84 & 0.25 & 0.04 \\
\hline Methionine & 0.79 & 0.70 & 0.69 & 0.65 & 0.55 & 0.03 & 0.15 \\
\hline Phenylalanine & 3.41 & 3.53 & 3.37 & 2.51 & 2.57 & 0.15 & 0.04 \\
\hline Threonine & 3.85 & 3.61 & 3.60 & 3.38 & 2.98 & 0.11 & 0.09 \\
\hline Tryptophan & 1.54 & 1.48 & 1.45 & 1.25 & 1.09 & 0.05 & 0.02 \\
\hline Valine & 4.89 & 4.53 & 4.54 & 4.12 & 3.65 & 0.14 & 0.02 \\
\hline TEAA $^{3}$ & 39.69 & 37.08 & 33.76 & 31.40 & 32.59 & 1.04 & 0.05 \\
\hline
\end{tabular}

${ }^{1}$ Standard error of mean; ${ }^{2}$ Essential amino acids; ${ }^{3}$ Total essential amino acids 
From Table 2 it is evident that substituting non-protein nitrogen (NPN) for true protein on an isonitrogenous basis has a more pronounced effect on the essential AA concentrations in the duodenum than the true RDP level. Increasing the supplemental $\mathrm{N}$ from urea decreased isoleucine, leucine, lysine, phenylalanine, tryptophan, valine and TEAA concentrations in the duodenum $(\mathrm{P} \leq 0.05)$ and tended to reduce threonine concentrations ( $\mathrm{P} \leq 0.09$ ). The decrease in branched-chain amino acids (BCAA's) is supported by the reduced branched-chain volatile fatty acid concentrations, reported by Nolte (2000), when substituting urea for true RDP, since BCAA's serve as precursors to branched-chain volatile fatty acids (Russell \& Sniffen, 1984). The duodenal histidine and methionine concentrations for the $100 \%$ urea-N treatment were also 28 and 30\% lower, respectively, than for the 100\% true RDP supplement. Maeng \& Baldwin (1976a) also indicated that urea alone resulted in lower bacterial growth rates than a combination of urea and AA's. Since almost all the essential AA's, except arginine which showed a variable response, tended to decrease as urea- $\mathrm{N}$ substituted true RDP, these results suggest that the duodenal essential AA profile is not qualitatively affected by protein source, but essential AA availability may be quantitatively reduced when true RDP is replaced by NPN. Nolte (2000) reported that increasing urea-N levels in isonitrogenous RDP supplements did not affect daily microbial $\mathrm{N}$ flow to the duodenum. Therefore, the reduced essential AA concentrations associated with increased urea levels suggest a decreased proportion of essential AA's:nonessential AA's in microbial protein. This may limit animal production and be part of the reason why natural protein is generally accepted as superior to NPN in terms of animal production (Helmer \& Bartley, 1971).

Table 3 The effect of increasing rumen degradable protein (RDP) levels and different RDP:non-protein nitrogen (NPN) ratios on the duodenal essential amino acid:lysine ratio of sheep fed low-quality forage

\begin{tabular}{|c|c|c|c|c|c|c|c|}
\hline \multirow{3}{*}{ Amino acid } & \multicolumn{5}{|c|}{ Supplemental RDP (g/d) } & \multirow{3}{*}{ SEM $^{1}$} & \multirow{3}{*}{$\mathrm{P}$} \\
\hline & 0 & 40 & 80 & 120 & 160 & & \\
\hline & \multicolumn{5}{|c|}{ Essential $\mathrm{AA}^{2}$ (g/100 g crude protein) } & & \\
\hline Arginine & 133.6 & 180.1 & 93.3 & 100.9 & 67.0 & 13.85 & 0.08 \\
\hline Histidine & 20.3 & 19.2 & 19.3 & 19.7 & 19.3 & 0.14 & 0.04 \\
\hline Isoleucine & 63.5 & 62.2 & 62.2 & 62.6 & 62.9 & 0.32 & 0.76 \\
\hline Leucine & 97.1 & 92.9 & 92.7 & 92.6 & 93.2 & 0.53 & 0.02 \\
\hline Lysine & 100 & 100 & 100 & 100 & 100 & & \\
\hline Methionine & 12.1 & 12.0 & 12.4 & 11.0 & 12.4 & 0.25 & 0.35 \\
\hline Phenylalanine & 58.8 & 55.8 & 56.0 & 55.6 & 55.9 & 0.35 & $<0.01$ \\
\hline Threonine & 62.8 & 62.2 & 61.1 & 60.2 & 60.3 & 0.30 & $<0.01$ \\
\hline Tryptophan & 25.0 & 28.5 & 33.0 & 33.6 & 36.7 & 0.96 & $<0.01$ \\
\hline \multirow[t]{4}{*}{ Valine } & 79.8 & 76.6 & 75.8 & 76.2 & 76.7 & 0.49 & 0.07 \\
\hline & \multicolumn{5}{|c|}{ Supplemental N from urea (\%) } & & \\
\hline & 0 & 25 & 50 & 75 & 100 & & \\
\hline & \multicolumn{5}{|c|}{ 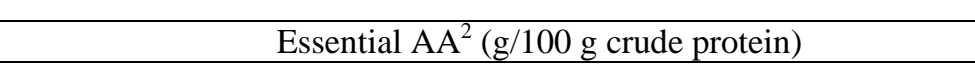 } & & \\
\hline Arginine & 86.4 & 90.2 & 61.9 & 81.8 & 181.3 & 14.52 & 0.04 \\
\hline Histidine & 19.2 & 22.3 & 18.7 & 18.9 & 19.2 & 0.52 & 0.23 \\
\hline Isoleucine & 60.1 & 52.9 & 59.6 & 60.5 & 61.3 & 1.04 & 0.09 \\
\hline Leucine & 87.6 & 81.3 & 88.9 & 90.6 & 91.8 & 1.57 & 0.32 \\
\hline Lysine & 100 & 100 & 100 & 100 & 100 & & \\
\hline Methionine & 11.7 & 10.5 & 11.3 & 11.9 & 11.4 & 0.36 & 0.85 \\
\hline Phenylalanine & 51.3 & 50.8 & 56.2 & 45.4 & 53.1 & 1.79 & 0.43 \\
\hline Threonine & 57.6 & 54.4 & 59.0 & 61.4 & 61.6 & 1.10 & 0.26 \\
\hline Tryptophan & 23.2 & 22.0 & 23.6 & 22.8 & 22.5 & 0.47 & 0.88 \\
\hline Valine & 73.2 & 67.5 & 74.5 & 74.8 & 75.5 & 1.14 & 0.22 \\
\hline
\end{tabular}

\footnotetext{
${ }^{1}$ Standard error of mean, ${ }^{2}$ Essential amino acids
} 
According to Zhang et al. (1986) the NPN content in the body varies with increasing body weight. Amino acid comparisons between animals of different body weights may therefore be inaccurate. To eliminate the influence of NPN and obtain a clearer picture of the AA profile, essential AA's can be expressed relative to lysine as an ideal protein ratio (Table 3). Lysine is chosen as a reference for ideal protein for several reasons: (1) Lysine and methionine are generally considered limiting in most ruminant diets (Rulquin \& Vérité, 1996), (2) Analysis of lysine content in feedstuffs is straightforward (Mack et al., 1999), (3) Lysine is only used for body protein accretion (Mack et al., 1999), (4) Lysine and methionine have frequently been studied as potential limiting AA's under a variety of conditions, providing a large body of information (Rulquin \& Vérité, 1996).

The comparison of essential AA:lysine ratios (Table 3) shows that histidine, leucine, phenylalanine and threonine ratios decreased as supplemental RDP increased $(\mathrm{P} \leq 0.04)$, and arginine and valine ratios tended to decrease ( $\mathrm{P} \leq 0.08$ ). For most of these AA's, the largest decrease occurred between 0 and $40 \mathrm{~g}$ supplemental RDP, whereafter the essential AA ratios showed little variation. Isoleucine and methionine ratios were unaffected $(\mathrm{P} \geq 0.35)$ as the supplemental protein level was raised. In contrast to the other essential AA's the tryptophan:lysine ratio increased ( $<<0.0001)$ as RDP supplements increased, suggesting that tryptophan synthesis might be dependent on peptides and AA's. The initial decrease in the ratios of essential AA's to lysine between the control treatment and $40 \mathrm{~g}$ supplemental RDP/d probably resulted from enhanced microbial growth rates (Argyle \& Baldwin, 1989; Nolte et al., 2003) that lead to reduced protein concentrations in rumen microbes (Rodriguez et al., 2000). Little variation in the duodenal essential AA profile occurred from 40 to $160 \mathrm{~g} \mathrm{RDP} / \mathrm{d}$, which is indicative of a relatively constant essential AA profile of microbial protein, irrespective of dietary alterations.

When urea- $\mathrm{N}$ was substituted for true RDP on a N-equivalent basis, only the relative arginine $(\mathrm{P}=$ 0.04) and isoleucine $(\mathrm{P}=0.09)$ concentrations appeared to be affected. Arginine showed a substantial increase at the $100 \%$ urea- $\mathrm{N}$ supplement and isoleucine seemed to decrease at the $25 \%$ urea- $\mathrm{N}$ treatment. For the other treatments the concentrations of these two AA's were relatively constant. The other essential AA's were not affected by treatment $(\mathrm{P} \geq 0.22)$, indicating that the duodenal essential AA pattern, predominantly derived from microbial protein, is relatively constant, irrespective of protein source. Purser \& Buechler (1966) also reported little variation in the AA composition of 22 strains of pure cultures of rumen organisms specifically selected for their differing substrate utilisation characteristics. Supporting evidence by Bergen et al. (1968) and Martin et al. (1996) also indicated that the AA composition of rumen microorganisms was independent of dietary changes. In contrast, Clark et al. (1992) reported variation in the AA profiles of rumen bacteria.

The daily flow of arginine to the duodenum was not affected by supplemental RDP level ( $\mathrm{P}=0.14$; Table 4). The flow of the other essential AA's to the duodenum increased as RDP level was raised (P $\leq$ $0.04)$, and TEAA flow tended to increase $(\mathrm{P}=0.07)$. It appears that the essential AA profile of rumen microbes is independent of dietary influences (MacRae \& Reeds, 1980; John, 1984), but the quantitative essential AA supply from microbial protein to the duodenum is improved by RDP supplementation when sheep are fed low quality forages. The ability of true RDP supplementation to enhance the daily flow of essential AA's to the duodenums of sheep consuming low quality roughage diets is indicative of a more active rumen microbial population and subsequent increased microbial efficiency and higher microbial $\mathrm{N}$ flow to the duodenum (Nolte et al., 2003). In addition, protein supplementation to ruminants offered low quality forages (<60 to $80 \mathrm{~g} \mathrm{CP/kg;} \mathrm{Kartchner,} \mathrm{1980)} \mathrm{increased} \mathrm{feed} \mathrm{intake} \mathrm{(DelCurto} \mathrm{et} \mathrm{al.,} \mathrm{1990;}$ Matejovsky \& Sanson, 1995), forage organic matter intake and digestible organic matter intake (Nolte et al., 2003). The increased flow of essential AA's to the duodenum therefore appears to result from the combined effects of an increased forage intake that might have caused a higher rumen outflow rate, which, together with the improved microbial efficiency resulted in an increased flow of microbial $\mathrm{N}$ to the small intestine. In contrast, Nolte et al. (2003) reported no response of RDP supplementation on fluid dilution rate, which implies that the increased duodenal flow of microbial N in RDP supplemented sheep consuming low quality, $\mathrm{N}$ deficient roughage diets probably originated from an improved microbial efficiency, stimulated by the supply of peptides, AA's and $\mathrm{NH}_{3}$ to the rumen microbes.

Sniffen \& Robinson (1987) stated that a number of factors, such as the amount and degradability of dietary protein, could impact on rumen microbial growth rate. Although higher microbial growth rates tended to decrease essential AA concentrations (Rodriguez et al., 2000) the increased numbers and activity 
of the rumen microbial population improved the quantitative essential AA availability at the duodenum. This is in agreement with Cecava \& Parker (1993) who also found that protein source has a larger effect on the quantity of AA's presented to the small intestine than on the AA profile.

Table 4 The effect of increasing rumen degradable protein (RDP) levels and different RDP:non-protein nitrogen (NPN) ratios on daily essential amino acid flow to the duodenum of sheep fed low quality forage

\begin{tabular}{|c|c|c|c|c|c|c|c|}
\hline \multirow{3}{*}{ Amino acid } & \multicolumn{5}{|c|}{ Supplemental RDP (g/d) } & \multirow{3}{*}{ SEM $^{1}$} & \multirow{3}{*}{$\mathrm{P}$} \\
\hline & 0 & 40 & 80 & 120 & 160 & & \\
\hline & \multicolumn{5}{|c|}{ Essential AA $^{2}(\mathrm{~g} / \mathrm{d})$} & & \\
\hline Arginine & 3.59 & 7.36 & 4.73 & 5.79 & 2.82 & 0.62 & 0.14 \\
\hline Histidine & 0.47 & 0.77 & 1.00 & 1.09 & 0.95 & 0.07 & 0.04 \\
\hline Isoleucine & 1.45 & 2.50 & 3.25 & 3.47 & 3.08 & 0.24 & 0.03 \\
\hline Leucine & 2.20 & 3.74 & 4.85 & 5.13 & 4.57 & 0.35 & 0.04 \\
\hline Lysine & 2.32 & 4.02 & 5.22 & 5.55 & 4.92 & 0.38 & 0.04 \\
\hline Methionine & 0.26 & 0.48 & 0.64 & 0.60 & 0.61 & 0.04 & 0.03 \\
\hline Phenylalanine & 1.35 & 2.24 & 2.91 & 3.07 & 2.75 & 0.21 & 0.04 \\
\hline Threonine & 1.44 & 2.50 & 3.20 & 3.33 & 2.96 & 0.23 & 0.04 \\
\hline Tryptophan & 0.53 & 0.88 & 1.20 & 1.25 & 1.10 & 0.08 & 0.03 \\
\hline Valine & 1.82 & 3.08 & 3.94 & 4.21 & 3.75 & 0.28 & 0.04 \\
\hline TEAA $^{3}$ & 15.43 & 27.57 & 30.94 & 33.50 & 27.49 & 2.18 & 0.07 \\
\hline
\end{tabular}

Supplemental N from urea (\%)

\begin{tabular}{|c|c|c|c|c|c|c|c|}
\hline & & & & & & & \\
\hline & 0 & 25 & 50 & 75 & 100 & & \\
\hline & \multicolumn{6}{|c|}{ Essential AA $^{2}(\mathrm{~g} / \mathrm{d})$} & \\
\hline Arginine & 2.67 & 3.14 & 1.98 & 2.05 & 3.28 & 0.28 & 0.47 \\
\hline Histidine & 0.62 & 0.89 & 0.61 & 0.48 & 0.38 & 0.06 & 0.13 \\
\hline Isoleucine & 1.95 & 1.86 & 1.96 & 1.54 & 1.22 & 0.11 & 0.14 \\
\hline Leucine & 2.84 & 2.85 & 2.92 & 2.30 & 1.83 & 0.16 & 0.14 \\
\hline Lysine & 3.23 & 3.75 & 3.30 & 2.54 & 1.99 & 0.23 & 0.10 \\
\hline Methionine & 0.38 & 0.36 & 0.36 & 0.30 & 0.22 & 0.02 & 0.05 \\
\hline Phenylalanine & 1.67 & 1.90 & 1.84 & 1.19 & 1.06 & 0.13 & 0.11 \\
\hline Threonine & 1.86 & 1.91 & 1.94 & 1.56 & 1.22 & 0.11 & 0.17 \\
\hline Tryptophan & 0.74 & 0.78 & 0.76 & 0.58 & 0.45 & 0.04 & 0.05 \\
\hline Valine & 2.37 & 2.40 & 2.45 & 1.90 & 1.50 & 0.14 & 0.13 \\
\hline TEAA $^{3}$ & 19.86 & 19.86 & 18.12 & 14.45 & 13.16 & 1.17 & 0.22 \\
\hline
\end{tabular}

${ }^{1}$ Standard error of mean, ${ }^{2}$ Essential amino acids, ${ }^{3}$ Total essential amino acids

Substituting urea for true protein on an isonitrogenous basis decreased the flow of methionine and tryptophan to the duodenum $(\mathrm{P}=0.05)$ and also tended to decrease the daily duodenal flow of lysine $(\mathrm{P}=$ 0.10). The duodenal flow of isoleucine, leucine, phenylalanine, threonine and valine also decreased numerically between 34 and 39\% when 100\% urea-N substituted true RDP ( $\mathrm{P} \geq 0.11)$. Consequently, the total essential AA flow to the duodenum was also numerically reduced as supplemental NPN contributions increased. Hume (1970) and Maeng et al. (1976) reported increased microbial protein yields when true protein $\mathrm{N}$ replaced urea- $\mathrm{N}$ in purified diets or in vitro studies. This decrease in essential AA flows to the duodenum as urea-N increased might be attributed to a reduced supply of AA's, peptides and branched-chain volatile fatty acids (BCVFA) from rumen proteolysis. These fermentation products are required for, or stimulatory of microbial growth (Bryant \& Robinson, 1962). When urea is substituted for true protein more ammonia and less AA's, peptides and BCVFA are formed in the rumen, which may decrease microbial growth (Hume, 1970; Maeng \& Baldwin, 1976b), resulting in reduced essential AA supplies to the duodenum. 
Generally, urea is inferior to true protein sources in terms of $\mathrm{N}$ retention for various kinds of ruminants (Helmer \& Bartley, 1971). In contrast, Cruz Soto et al. (1994) stated that the benefits of pre-formed AA's on microbial growth cannot be realised when growth rate is limited by energy availability, as on high cellulose diets. Carro \& Miller (1999) contradicted these findings by observing increased microbial efficiencies and microbial $\mathrm{N}$ flows to the duodenum in the presence of pre-formed AA's on high fibre diets, corroborating that $\mathrm{N}$ is the first limiting nutrient on low quality roughage diets. A combination of true RDP and NPN seemed to alleviate the $\mathrm{N}$ deficiency in low quality roughage diets most efficiently (Nolte, 2000).

\section{Conclusion}

The results from the present study suggest that the qualitative essential AA profile in the duodenum of sheep fed low quality forages is to a large extent independent of dietary protein level or source. From a quantitative perspective it appears that true RDP has a higher stimulatory effect on microbial essential AA flow to the duodenum than NPN. In corroboration, various studies conducted with animals on widely differing diets have also indicated remarkable similarities in the essential AA profiles of microbial protein. This implies that the postruminal essential AA supply from microbial protein can be predicted for animals utilising a wide range of different diets. The available essential AA's can thus be compared to the essential AA requirements for specific production stages and imbalances accordingly corrected via undegradable protein supplements.

\section{Acknowledgement}

Sincere appreciation to the Verwoerd Trust for their financial support of this study and to G.F. Jordaan for assistance with the statistical analyses.

\section{References}

Aharoni, Y., Tagari, H. \& Boston, R.C., 1991. A new approach to the quantitative estimation of nitrogen metabolic pathways in the rumen. Br. J. Nutr. 66, 407-422.

AOAC, 1995. Official methods of analysis (15th ed.). Association of Official Analytical Chemists, Arlington, Virginia, USA.

Argyle, J.L. \& Baldwin, R.L., 1989. Effects of amino acids and peptides on rumen microbial growth yields. J. Dairy Sci. 72, 2017-2027.

Balch, C.C., 1967. Problems in predicting the value of non-protein nitrogen as a substitute for protein in rations for farm ruminants. World Rev. Anim. Prod. 3, 84-91.

Bergen, W.G., Purser, D.B. \& Cline, J.H., 1968. Effect of ration on the nutritive quality of rumen microbial protein. J. Anim. Sci. 27, 1497-1501.

Broderick, G.A., 1994. Quantifying forage protein quality. In: Forage Quality, Evaluation and Utilisation. Ed. Fahey Jr, G.C., Collins, M., Mertens, D.R. \& Moser, L.E., ASA-CSSA-SSSA, Madison, WI. pp. 200-228.

Bryant, M.P. \& Robinson, I.M., 1962. Some nutritional characteristics of predominant culturable rumen bacteria. J. Bacteriol. 84, 605-614.

Carro, M.D. \& Miller, E.L., 1999. Effect of supplementing a fibre basal diet with different nitrogen forms on ruminal fermentation and microbial growth in an in vitro semi-continuous culture system (RUSITEC). Br. J. Nutr. 82, 149-157.

Cecava, M.J. \& Parker, J.E., 1993. Intestinal supply of amino acids in steers fed ruminally degradable and undegradable protein sources alone and in combination. J. Anim. Sci. 71, 1596-1605.

Clark, J.H., Klusmeyer, T.H. \& Cameron, M.R., 1992. Microbial protein synthesis and flows of nitrogen fractions to the duodenum of dairy cows. J. Dairy Sci. 75, 2304-2323.

Cruz Soto, R., Muhammed, S.A., Newbold, C.J., Stewart, C.S. \& Wallace, R.J., 1994. Influence of peptides, amino acids and urea on microbial activity in the rumen of sheep receiving grass hay and on the growth of rumen bacteria in vitro. Anim. Feed Sci. Technol. 49, 151-161.

Del Curto, T., Cochran, R.C., Harmon, D.L., Beharka, A.A., Jacques, K.A., Towne, G. \& Vanzant, E.S., 1990. Supplementation of dormant tallgrass-prairie forage: 1. Influence of varying supplemental protein and (or) energy levels on forage utilisation characteristics of beef steers in confinement. J. Anim. Sci. 68, 515-531. 
Firkins, J.L., Berger, L.L., Merchen, N.R. \& Fahey Jr, G.C., 1986. Effect of forage particle size, level of feed intake and supplemental protein degradability on microbial protein synthesis and site of nutrient digestion in steers. J. Anim. Sci. 62, 1081-1094.

Freeman, A.S., Galyean, M.L. \& Caton, J.S., 1992. Effects of supplemental protein percentage and feeding level on intake, ruminal fermentation, and digesta passage in beef steers fed prairie hay. J. Anim. Sci. 70, 1562-1576.

Hannah, S.M., Cochran, R.C., Vanzant, E.S. \& Harmon, D.L., 1991. Influence of protein supplementation on site and extent of digestion, forage intake, and nutrient flow characteristics in steers consuming dormant bluestem-range forage. J. Anim. Sci. 69, 2624-2633.

Helmer, L.G. \& Bartley, E.E., 1971. Progress in the utilisation of urea as a protein replacer for ruminants. A review. J. Dairy Sci. 54, 25-51.

Henning, P.H., Steyn, D.G. \& Meissner, H.H., 1993. Effect of synchronization of energy and nitrogen supply on ruminal characteristics and microbial growth. J. Anim. Sci. 71, 2516-2528.

Hume, I.D., 1970. Synthesis of microbial protein in the rumen. III. The effect of dietary protein. Aust. J. Agric. Res. 21, 305-314.

John, A., 1984. Effects of feeding frequency and level of feed intake on chemical composition of rumen bacteria. J. Agric. Sci., Camb. 102, 45-57.

Kang-Meznarich, J.H. \& Broderick, G.A., 1980. Effects of incremental urea supplementation on ruminal ammonia concentration and bacterial protein formation. J. Anim. Sci. 51, 422-431.

Kartchner, R.J. 1980. Effects of protein and energy supplementation of cows grazing native winter range forage on intake and digestibility. J. Anim. Sci. 51, 432-438.

Kempton, T.J. \& Leng, R.A., 1979. Protein nutrition of growing lambs: 1. Responses in growth and rumen function to supplementation of a low-protein-cellulosic diet with either urea, casein or formaldehydetreated casein. Br. J. Nutr. 42, 289-302.

Krishnamoorthy, U., Sniffen, C.J., Stern, M.D. \& Van Soest, P.J., 1983. Evaluation of a mathematical model of rumen digestion and an in vitro simulation of rumen proteolysis to estimate the rumen-undegraded nitrogen content of feedstuffs. Br. J. Nutr. 50, 555-568.

Leibholz, J., 1972. Nitrogen metabolism in sheep. II. The flow of amino acids into the duodenum from dietary and microbial sources. Aust. J. Agric. Res. 23, 1073-1083.

MacRae, J.C. \& Reeds, P.J., 1980. Prediction of protein deposition in ruminants. In: Protein Deposition in Animals. Eds. Buttery, P.J. \& Lindsay, D.B., Butterworths, London. p. 225.

Maeng, W.J. \& Baldwin, R.L., 1976a. Factors influencing rumen microbial growth rates and yields: Effects of urea and amino acids over time. J. Dairy Sci. 59, 643-647.

Maeng, W.J. \& Baldwin, R.L., 1976b. Factors influencing rumen microbial growth rates and yields: Effect of amino acid additions to a purified diet with nitrogen from urea. J. Dairy Sci. 59, 648-655.

Maeng, W.J., Van Nevel, C.J., Baldwin, R.L. \& Morris, J.G., 1976. Rumen microbial growth rates and yields: Effect of amino acids and protein. J. Dairy Sci. 59, 69-79.

Martin, C., Bernard, L. \& Michalet-Doreau, B., 1996. Influence of sampling time and diet on amino acid composition of protozoal and bacterial fractions from bovine ruminal contents. J. Anim. Sci. 74, 1157-1163.

Matejovsky, K.M. \& Sanson, D.W., 1995. Intake and digestion of low-, medium-, and high-quality grass hays by lambs receiving increasing levels of corn supplementation. J. Anim. Sci. 73, 2156-2163.

Mawuenyegah, P.O., Shem, M.N., Warly, L. \& Fujihara, T., 1997. Effect of supplementary feeding with protein and energy on digestion and rumination behaviour of sheep consuming straw diets. J. Agric. Sci., Camb. 129, 479-484.

Nolan, J., 1975. Quantitative models of nitrogen metabolism in sheep. In: Digestion and Metabolism in the Ruminant. Eds. McDonald, I.W. \& Warner, A.C.I., University of New England Publishing Unit, Armidale, Australia. p. 416.

Nolte, J. vanE., 2000. An evaluation of rumen degradable protein and nonprotein nitrogen on intake and digestion by Dohne Merino sheep fed wheat straw. M.Sc. (Agric) thesis, University of Stellenbosch, Stellenbosch, South Africa.

Nolte, J. vanE., Ferreira, A.V. \& Köster, H.H., 2003. Effect of different rumen degradable protein levels on the utilisation of wheat straw by Dohne Merino wethers. Anim. Sci. 76, 319-326. 
NRC, 2001. Nutrient Requirements of Dairy Cattle. $7^{\text {th }}$ revised Ed. National Academy Press, Washington, D.C., USA.

Owens, F.N. \& Bergen, W.G., 1983. Nitrogen metabolism of ruminant animals: Historical perspective, current understanding and future implications. J. Anim. Sci. 57 (Suppl. 2), 498-518.

Owens, F.N. \& Goetsch, A.L., 1986. Digesta passage and microbial protein synthesis. In: Control of Digestion and Metabolism in Ruminants. Eds. Milligan, L.P., Grovum, W.L. \& Dobson, A., PrenticeHall, Englewood Cliffs, NJ. pp. 196-223.

Purser, D.B. \& Buechler, S.M., 1966. Amino acid composition of rumen organisms. J. Dairy Sci. 49, 8184.

Rodriguez, C.A., Gonzalez, J., Alvir, M.R., Repetto, J.L., Centeno, C. \& Lamrani, F., 2000. Composition of bacteria harvested from the liquid and solid fractions of the rumen of sheep as influenced by feed intake. Br. J. Nutr. 84, 369-376.

Rulquin, H., Guinard, J. \& Vérité, R., 1998. Variation of amino acid content in the small intestine digesta of cattle: development of a prediction model. Livest. Prod. Sci. 53, 1-13.

Russell, J.B. \& Sniffen, C.J., 1984. Effect of carbon-4 and carbon-5 volatile fatty acids on growth of mixed rumen bacteria in vitro. J. Dairy Sci. 67, 987-994.

Russell, J.B., O`Connor, J.D., Fox, D.G., Van Soest, P.J. \& Sniffen, C.J., 1992. A net carbohydrate and protein system for evaluating cattle diets. I. Ruminal fermentation. J. Anim. Sci. 70, 3551-3561.

SAS, 1994. Statistical Analysis Systems user's guide (Version 6, Fourth ed.). SAS Institute Inc., Cary, NC, USA.

Sniffen, C.J. \& Robinson, P.H., 1987. Microbial growth and flow as influenced by dietary manipulations. J. Dairy Sci. 70, 425-441.

Storm, E. \& Ørskov, E.R., 1983. The nutritive value of rumen micro-organisms in ruminants. I. Large-scale isolation and chemical composition of rumen micro-organisms. Br. J. Nutr. 50, 463-470.

Uden, P., Colucci, P.E. \& Van Soest, P.J., 1980. Investigation of chromium, cerium and cobalt as markers in digesta. Rate of passage studies. J. Sci. Food Agric. 31, 625-632.

Van Soest, P.J. \& Wine, R.H., 1967. Use of detergents in the analysis of fibrous feeds. IV. J. AOAC. 50, 50-55.

Warner, A.C.I. \& Stacy, B.D., 1968. The fate of water in the rumen. 1. A critical appraisal of the use of soluble markers. Br. J. Nutr. 22, 369-387. 